\title{
Commentary: Stem cell therapy for single-ventricle congenital heart disease: Exciting, but a long way to go
}

Jacob R. Miller, MD, and Pirooz Eghtesady, MD, PhD

\author{
From St Louis Children's Hospital, Washington University School of Medicine, St Louis, Mo. \\ Disclosures: Authors have nothing to disclose with regard to commercial support. \\ Received for publication May 14, 2019; accepted for publication May 15, 2019; available ahead of print July 2 , \\ 2019. \\ Address for reprints: Pirooz Eghtesady, MD, PhD, St Louis Children's Hospital, One Children's Place, Suite 5 S, \\ St Louis, MO 63110 (E-mail: eghtesadyp@wudosis.wustl.edu). \\ J Thorac Cardiovasc Surg 2019;158:851-2 \\ $0022-5223 / \$ 36.00$ \\ Copyright (C) 2019 by The American Association for Thoracic Surgery \\ https://doi.org/10.1016/j.jtcvs.2019.05.041
}

The diagnosis of a congenital heart defect necessitating single-ventricle (SV) palliation obligates a patient and family to a substantial commitment to their child's health. Palliation requires 3 operative interventions, and even then, the patient is left with a single functional ventricle. Because SV palliation was never designed to support both the systemic and pulmonary circulations, the eventual development of heart failure is an inevitability, a matter of time. Although many patients will survive well into adulthood before the development of heart failure, many will not. ${ }^{1}$ As patients with SV circulations have heart failure develop, the only remaining treatment option is transplantation. ${ }^{2}$

Recently, stem cell therapy has been proposed to prevent the development of heart failure in patients with SV circulations. Although the mechanisms are unclear, they likely involve both the maturation of these cells into functional myocardium or endothelial cells and the activation of juxtacrine and paracrine mechanisms to improve angiogenesis and enhance cellular ability to mitigate oxidative stress. ${ }^{3}$

In this issue of the Journal, Sano and colleagues ${ }^{4}$ provide their expert opinion on the current state of cardiac stem cell therapy for pediatric patients. Sano and colleagues ${ }^{4}$ are to be congratulated not only for this excellent review but also for their many contributions to the field. The recent results of the TICAP (Transcoronary Infusion of Cardiac Progenitor Cells in Patients With Single-Ventricle Physiology) trial $^{5}$ and the PERSEUS (Cardiac Progenitor Cell Infusion to Treat Univentricular Heart Disease) trial, ${ }^{6}$ in which these authors are involved, are encouraging. Initially, they demonstrated the safety of intracoronary stem cell injection of cardiosphere-derived cells, without an adverse event in either trial. In addition, they demonstrated improved ventricular function (higher ejection fraction and lower ventricular volumes), reduced heart failure (lower B-type natriuretic peptide and less fibrosis), increased weight for age, and improved quality of life.

Despite these findings, as is true for any potentially novel discovery, before stem cell use can become a more operation. $^{8}$

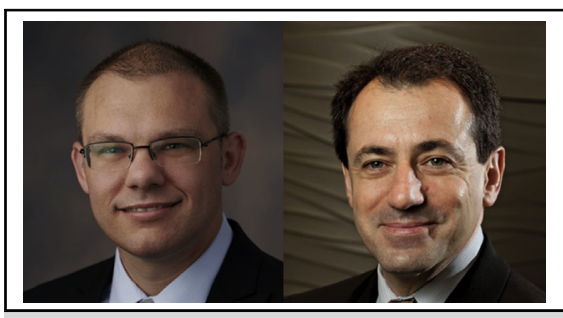

Jacob R. Miller, MD (left), and Pirooz Eghtesady, MD, $\mathrm{PhD}$ (right)

\section{Central Message}

In the short term, stem cell therapy after singleventricle palliation is safe and has promising outcomes. The long-term impact and optimal strategy, however, require many questions to be answered.

See Article page 845 .

clinically relevant treatment option, there remain many more questions than answers. What is the long-term effect on cardiac function? Will these patients need to be redosed? What type of stem cell will lead to the best results? How and when should the stem cells be harvested? How and when should they be administered? Will the impact of this therapy be more pronounced for patients with systolic or diastolic dysfunction? What is the overall mechanism, and how can we optimize it? Can stem cells be used as a rescue therapy? Many different studies performed in the course of many years will be necessary to answer this multitude of questions. A phase I/IIb randomized trial from the University of Maryland, the ELPIS (Longeveron Mesenchymal Stem Cells [LMSCs] Delivered During Stage II Surgery for Hypoplastic Left Heart Syndrome) trial, which uses bone marrow-derived mesenchymal stem cells injected intramyocardially during the time of the stage II operation, is currently underway. ${ }^{7}$ In addition, a study from the Mayo Clinic will use umbilical cord blood-derived stem cells administered intramyocardially at the time of the stage II

Current data do indicate that these strategies are safe, at least in the short-term. A lot, however, remains to be discovered before consistent clinical use. These successful shortterm clinical trials will continue to push the field forward, provide enthusiasm, and lead to the continued evaluation of stem cell therapy in pediatric patients with SV palliation. Overall, the field is evolving rapidly, and it is very exciting. 


\section{References}

1. d'Udekem Y, Iyengar AJ, Galati JC, Forsdick V, Weintraub RG, Wheaton GR, et al. Redefining expectations of long-term survival after the Fontan procedure: twenty-five years of follow-up from the entire population of Australia and New Zealand. Circulation. 2014;130(11 Suppl 1):S32-8.

2. Voeller RK, Epstein DJ, Guthrie TJ, Gandhi SK, Canter CE, Huddleston CB. Trends in the indications and survival in pediatric heart transplants: a 24-year single-center experience in 307 patients. Ann Thorac Surg. 2012;94:807-15; discussion 815-6.

3. Si MS, Ohye RG. Stem cell therapy for the systemic right ventricle. Expert Rev Cardiovasc Ther. 2017;15:813-23.

4. Sano S, Ishigami S, Sano T. New era of heart failure therapy in pediatrics: cardiac stem cell therapy on the start line. J Thorac Cardiovasc Surg. 2019;158:845-9.

5. Tarui S, Ishigami S, Ousaka D, Kasahara S, Ohtsuki S, Sano S, et al. Transcoronary infusion of cardiac progenitor cells in hypoplastic left heart syndrome: three-year follow-up of the transcoronary infusion of cardiac progenitor cells in Patients with single-ventricle physiology (TICAP) trial. J Thorac Cardiovasc Surg. 2015;150: 1198-207. 1208.e1-2.

6. Ishigami S, Ohtsuki S, Eitoku T, Ousaka D, Kondo M, Kurita Y, et al. Intracoronary cardiac progenitor cells in single ventricle physiology: the PERSEUS (cardiac progenitor cell infusion to treat univentricular heart disease) randomized phase 2 trial. Circ Res. 2017;120:1162-73.

7. Kaushal S, Wehman B, Pietris N, Naughton C, Bentzen SM, Bigham G, et al. Study design and rationale for ELPIS: a phase I/IIb randomized pilot study of allogeneic human mesenchymal stem cell injection in patients with hypoplastic left heart syndrome. Am Heart J. 2017;192:48-56.

8. Burkhart HM, Qureshi MY, Peral SC, O'Leary PW, Olson TM, Cetta F, et al. Regenerative therapy for hypoplastic left heart syndrome: first report of intraoperative intramyocardial injection of autologous umbilical-cord blood-derived cells. J Thorac Cardiovasc Surg. 2015;149:e35-7. 